\title{
The socio-economic role of tree-borne oilseeds in rural livelihood: a case study in Karnataka State, India
}

\author{
Katsuhiro Fukushima ${ }^{1}$, Misa Masuda ${ }^{2, *}$, Yukako Tani ${ }^{3}$, and Kaori Shiga ${ }^{1}$ \\ ${ }^{1}$ Graduate School of Life and Environmental Sciences, University of Tsukuba, Ibaraki 305-8572, Japan \\ ${ }^{2}$ Faculty of Life and Environmental Sciences, University of Tsukuba, Ibaraki 305-8572, Japan \\ ${ }^{3}$ Faculty of Economics, Tohoku Gakuin University, Miyagi 980-8511, Japan \\ *Corresponding author: E-mail: masuda.misa.gm@u.tsukuba.ac.jp, Tel: 029-853-4610, Fax: 029-853-4761
}

\begin{abstract}
Biofuel production on degraded lands with tree-borne oilseeds (TBOs) is assumed to have less negative impact on the forests and food supply, and to have economic benefit for the rural poor. India has launched a national policy to encourage production of TBOs. Our aim was to determine how TBOs are produced, what kind of socio-economic roles they play in the rural economy, and to discuss whether those roles will be affected if the demand for biofuel increases. We interviewed farmers, middlemen, and refining factories in Karnataka State about the production and sale of the TBOs, Neem (Azadirachta indica) and Pongamia (Pongamia pinnata). Regarding TBO production, we found that the trees were multi-purpose and that oil extraction from seeds was one of several utilities. The trees were arranged along field boundaries, probably to avoid competition with crops, to make it easier to collect the seeds, and to avoid interfering with ploughs. Seeds were collected from the ground, mainly by women, during the no-harvest season, providing households with a small additional income. TBOs provide a minor subsistence, allowing treeless people to collect seeds from the trees held by others without charge; thus the seeds could be regarded as a common pool resource. At present, the production of TBOs at the research site seemed to have a small ecological impact, low food conflict, and certain contribution to carbon sequestration. Once TBOs gain greater value, the nature of this resource might change, becoming exclusive private property. Intervention to promote the reproduction of TBO trees is recommended since only one household surveyed has planted TBOs in the past.
\end{abstract}

Key wards: biodiesel, common pool resources, neem, pongamia, NTFP

\section{INTRODUCTION}

Energy demand in India has increased with economic growth. Ranked as the fifth largest net oil importer in the world (EIA 2011), the country is facing the challenges of meeting the growing energy demand and, at the same time, of reducing the increasing dependency on imported energy sources. To ensure energy security, the Government of India approved the National Policy on Biofuels in 2009 and proposed a general target of $20 \%$ bioethanol and 20\% biodiesel blending by 2017 (MNRE 2009). However, it is forecasted that 3.82 to 93.26 million ha, depending on the crops and total energy demand, will be required to meet the $20 \%$ target of biofuels as a whole (Ravindranath et al. 2010). The land area to meet the target of biodiesel is estimated to range from 3.12 (oil palm-low scenario) to 66.98 million ha (Jatropha-high scenario) (ibid.). Whether India has enough wasteland to expand biofuel crop cultivation comes under question (Agoramoorthy et al. 2009).

The National Policy on Biofuel refers to this concern: the focus for development of biofuels in India will be to utilize waste and degraded forest and non-forest lands only for cultivation of shrubs and trees bearing non-edible oil seeds for production of bio-diesel' (MNRE 2009). We can take from this statement that unproductive land and collectively dubbed tree-borne oilseeds (TBOs) are the targets of this policy; it is estimated that over 400 species have been traditionally utilized as TBOs (Subramanian et al. 2005). Hereinafter, the term TBO will be used for both trees and seeds.

Since studies regarding raw-material production are limited, our aim was to explore how TBOs are actually produced and what kind of socio-economic roles they play in rural livelihoods. TBOs are considered Non-timber Forest Products (NTFPs), and can be planted both inside and outside forests. For the latter, spatial arrangements range from monoculture-type plantations to agroforestrytype combinations with other crops. An initiative taken by the Indian Institute of Forest Management (IIFM) (2001) developed Criteria and Indicators for Sustainable Management of Trees Outside Forests, in which growing 
trees on farmland is listed in the tree arrangements necessary to be enhanced in India. Jambulingam and Fernandes (1986) listed 36 tree species kept on bunds and boundaries, homesteads, or scattered over the land in Tamil Nadu, a neighboring state of Karnataka. Most of the trees were utilized for fodder and fuelwood, and oil was produced from three species, Bassia latifolia, Calophyllum inophyllum and Pongamia pinnata. Trees on farms provide various materials for the local people's daily lives as well as income during the dry season when there is no crop (Fonzen and Oberholzer 1984, Fernandes 1986, Newman 1997). However, trees on farmland are rather suited for local markets, and establishment of an extensive distribution network will be needed to to make TBOs an effective source of biodiesel.

The growing demand for TBOs as a biodiesel source may change their role in the rural economy. Previous studies have focused on NTFPs inside forests, emphasized their roles for minor subsistence, and pointed out the higher dependency of the socially disadvantaged on NTFPs. Belcher et al. (2005), analyzing 61 cases from 25 countries, found that people tended to invest in NTFPs where the market was sufficiently attractive and land/ resource tenure was secure. However, they warned that there should be careful consideration since the process of commercialization may sometimes have an anti-poor bias.' With the development of commercialization, some cases reported that poorer producers started to be excluded from production because they lacked requisites such as land and capital to intensify their activities (Kusters and Belcher 2004, Sunderlin et al. 2005, Belcher 2005, Kusters et al. 2006). In other cases, middlemen made a larger profit than raw-material producers, and women did not have control over the income generated by NTFPs (Pérez and Arnold 1996, Wollenberg and Ingles 1998, Neumann and Hirsch 2000). It is anticipated that the increasing demand for biodiesel might trigger investment and result in the enclosure of land and resources, leading to the exclusion of the socially weak once depending on TBOs for their subsistence.

To find the actual constraints in biodiesel production in India, Altenburg et al. (2009) conducted an extensive survey in five states with proactive policies on biodiesel, identified a total of 13 existing or under planning cases of TBO-based cultivation, and categorized them into three types: government-centered ( 2 cases), corporate-centered ( 3 cases), and farmer-centered (8 cases) cultivation. The government-centered TBO cultivation was de facto conducted under Joint Forest Management, but red tape resulted in economic instability. Conversely, in corporate- centered TBO cultivation, private investors sought economic profit, and thus it took the form of large-scale monoculture. The key for further expansion of this type is, as Agoramoorthy et al. (2009) also pointed out, whether enough land is available.

Of eight farmer-centered practices, one case in Karnataka State was formed under a free market mechanism without any external inputs. TBOs grown on farmland were sold to middlemen and processed locally. The attempt of Bangalore Metropolitan Transport Corporation (BMTC) to blend biodiesel might have supported this mechanism. BMTC's proposal was validated as a Clean Development Mechanism project, and its contribution to social wellbeing by utilizing biofuel produced from locally grown trees was emphasized in the Project Design Document (UNFCCC 2007). We focused on this case in Karnataka because the implications will continue to be applicable once other farmer-centered cases, which currently receive support from the government or NGOs, are established and start to seek their own financial basis.

The TBO cultivation types categorized by Altenburg et al. (2009) correspond to the spatial arrangement of TBOs: government-centered corresponds to TBOs inside forests, corporate-centered to those outside forests, and farmer-centered to agroforestry or more extensive practices (Fig. 1). We will first describe how the TBOs were spatially distributed, utilized, and regenerated. Next, based on the arguments in previous studies, we will elucidate who engaged in production and how production was linked to the market. Then, we will discuss whether the roles of the TBOs in rural socio-economy will be affected when the demand for sources for biodiesel

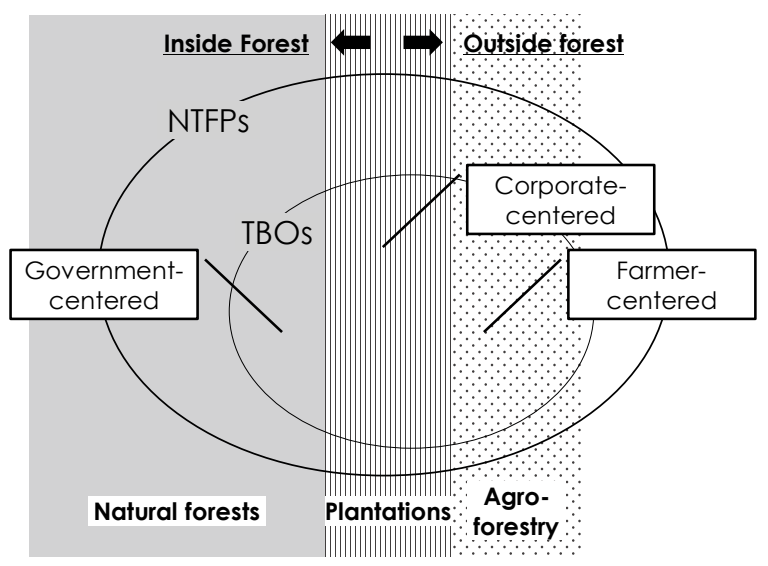

Fig. 1. Spatial distribution of NTFPs and TBOs, and TBObased cultivation categorized by Altenburg et al. (2009). 
increases.

\section{STUDY SITE AND METHODS}

\section{Outline of the study site}

Karnataka State is located in the southwest of the Indian sub-continent. The Western Ghats mountain range runs from the north to south in the western part of the state. The population density was 276 people $\cdot \mathrm{km}^{-2}$ in 2001 and, provisionally, 319 people $\cdot \mathrm{km}^{-2}$ based on the results of the 2011 census (Kumar 2011). This is lower than the national average of 325 in 2001 and 382 in 2011, probably because of the drier climate. Among various TBOs with potential as raw materials for biodiesel, Neem (Azadirachta indica) and Pongamia (Pongamia pinnata) were already traded in Karnataka State (RDPR 2009). Utilization of Pongamia for oil was also reported in adjacent Tamil Nadu State (Jambulingam and Fernandes 1986).

Trade of agricultural crops in Karnataka was partly controlled by the State Government's Agricultural Marketing Board. Under this Board, there were 145 Agriculture Produce Marketing Committees (APMCs) that were functioning as trading centers. There were a total of 28 APMCs that traded TBOs, of which 10 traded only Neem, 8 traded only Pongamia, and 10 traded both. Gauribidanur APMC in Chikkaballapur district, a district located near Bengaluru, the state capital (Fig. 2), traded the largest amount of both Neem and Pongamia. The population density of the district was 273 people $\cdot \mathrm{km}^{-2}$ in 2001 and 298 people $\cdot \mathrm{km}^{-2}$ in 2011 (Kumar 2011). The rainy season ranges from April to October, and the mean annual rainfall from 1981 to 2004 was $821 \mathrm{~mm}$ (BES 2009). Based on the information obtained from the factories and the middlemen in Gauribidanur taluk, we selected D Ward/Village where production of oilseeds was most active.

The population density in Gauribidanur taluk was 303 people $\cdot \mathrm{km}^{-2}$, slightly higher than the average of the state and the district (RDPR 2009). The main industry was also agriculture, and production of maize was particularly popular. D Village is located about five kilometers southwest of the center of Gauribidanur taluk. There was no irrigation system in D Village. The main crops were maize and millet, with several kinds of pulses mixed in.

\section{Data collection and analysis}

The population of D Village in 2008 was 945 people (208

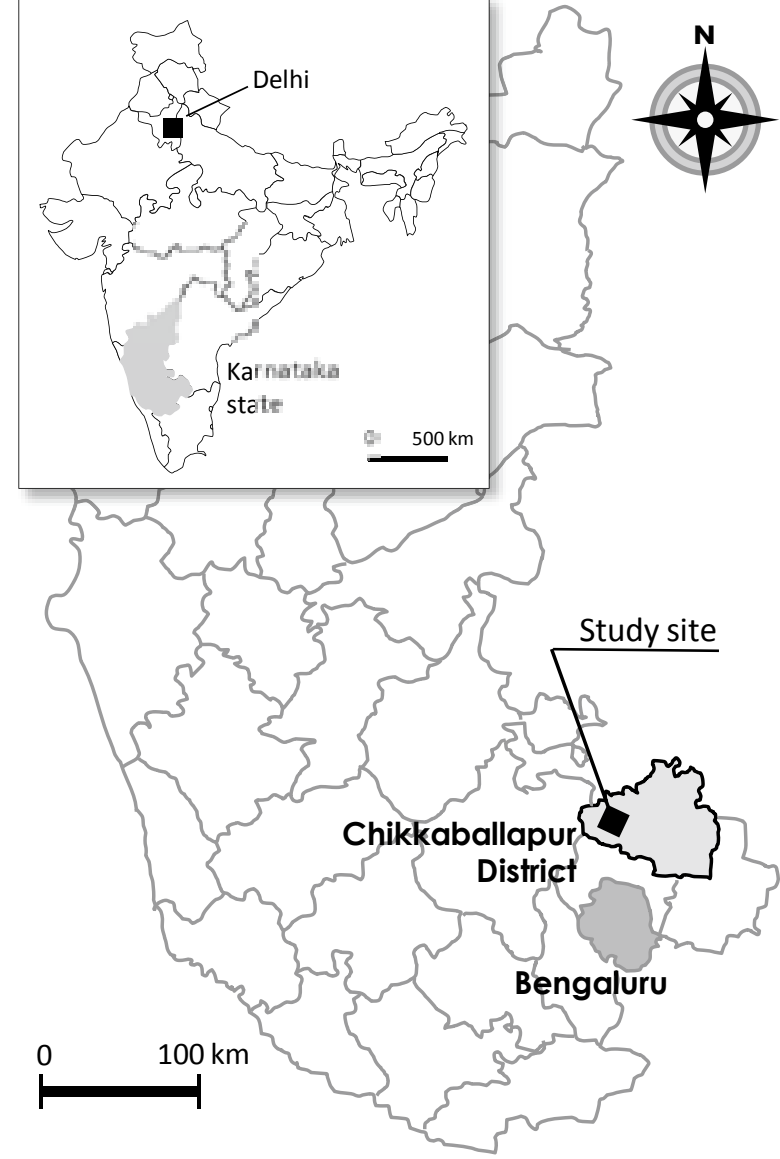

Fig. 2. The location of the study site.

households) (Gedare Grama Panchayat 2008). We randomly selected 52 households from the voting list, 25\% of the listed households, and visited them, but could not meet two households during the survey. We interviewed 50 households about their farming system involving TBOs (spatial arrangements and utilization of the TBOs, social attributes of the TBO collecting households and collectors, and economic significance of TBOs for the household economy) using a semi-structured questionnaire. We also interviewed three oil mills and five middlemen in Gauribidanur, a commercial center of the district.

We considered the husband in nuclear families (31 households), and the husband of the eldest generation in extended families (19 households) as the household head. All household members 15 years old and above were counted as part of the workforce, except for 83 people who attended school and an 80-year-old woman who did not engage in any labor for the period under survey. Thus the work force was calculated as 169 people.

TBOs were grown on private land, but the interviews 
revealed that landless people were also involved in TBO collection and sale as we discuss later. Therefore, we divided the households into four groups based on their relation with TBOs: Own and Collect group (abbreviated as $\mathrm{OC})$, Own only (O), Collect only (C), and no trees and no collection $(\mathrm{N})$. With an assumption that the $\mathrm{C}$ group could be the weakest social group, we focused mainly on them and compared their income and land ownership with the other groups. We did not include TBO production for self-consumption since we intended to predict the future market demand on the already established production system. The term 'TBO collector' was applied to those who took part in collecting TBOs for sales during the past year, from August 2008 to July 2009, and the term 'TBO collecting household' refers to households that include at least one TBO collector. For the statistical analysis, we used SPSS PASW Statistics 18 and SSRI Excel Statistics 2008.

\section{RESULTS}

\section{Economic activities of the sample households}

Out of the 50 sample households, seven households did not own any land and worked as wage laborers (13 people), of which three households had income from livestock, and one received supplies from their children. Besides agricultural crops, 25 households obtained income from livestock, one from firewood collected from farmland, 33 from wage-labors, and 7 received support from their children.
The livestock kept by the sample households were cows, buffalos, sheep, goats and chickens. Cows and buffalos were for milk or for ploughing. Those who did not own any agricultural land maintained some livestock through grazing or by purchasing their feed. Permanently employed people were all men, 13 of a total of 61 employees, and 11 people had attended school for more than 7 years. The majority of the daily wage laborers were working on farmland in the village.

Among the 43 households that owned farmland, the percentage of the households that planted maize, millet, pulses and groundnuts were 81.4, 62.8, 46.5 and 39.5, respectively. Maize and groundnuts were mainly for cash income, while millet and pulses were domestically consumed. Both Neem and Pongamia were harvested when there was no income from agricultural crops: during the sowing period (Neem) and during the dry season (Pongamia) (Fig. 3).

\section{Purpose for holding TBOs and their spatial allocation on farmland}

Of 50 sample households, 30 households owned the TBOs, of which 14 had only Neem, 2 had only Pongamia, and 14 had both. The major reason for growing trees on their farmland differed between Neem and Pongamia. For Neem, it was for wood supply $(50.0 \%$ of 28 households), seed collection (25.0\%), and feed supply (17.9\%). In contrast, Pongamia was for seed collection (56.3\% of 16 households) and fuelwood supply (31.3\%). The wood of Pongamia is vulnerable against pests and not

\begin{tabular}{|c|c|c|c|c|c|c|c|c|c|c|c|c|c|}
\hline \multirow{2}{*}{ Main crops } & \multirow{2}{*}{$\begin{array}{l}\text { Household cultivated } \\
\text { (\% to the total sample } \\
\text { HH) }\end{array}$} & \multicolumn{7}{|c|}{ Rainy season } & \multicolumn{5}{|c|}{ Dry season } \\
\hline & & 4 & 5 & 6 & 7 & 8 & 9 & 10 & 11 & 12 & 1 & 2 & 3 \\
\hline Maize & 81.4 & & & \multicolumn{2}{|c|}{ Sowing } & & & \multicolumn{3}{|c|}{ Harvesting } & & & \\
\hline Millet & 62.8 & & & \multicolumn{2}{|c|}{ Sowing } & & & \multicolumn{3}{|c|}{ Harvesting } & & & \\
\hline Dhal & 46.5 & & & \multicolumn{2}{|c|}{ Sowing } & & & \multicolumn{3}{|c|}{ Harvesting } & & & \\
\hline Groundnut & 39.5 & & & \multicolumn{2}{|c|}{ Sowing } & & & \multicolumn{3}{|c|}{ Harvesting } & & & \\
\hline Coconut & 4.7 & \multicolumn{12}{|c|}{ Harvesting } \\
\hline Neem & 65.1 & \multicolumn{4}{|c|}{ Harvesting } & & & & & & & & \\
\hline Pongamia & 37.2 & & & & & & & & & & & & ting \\
\hline
\end{tabular}

Fig. 3. Sowing and harvesting seasons of the main crops and the percentage of households cultivating the crops in 2008/2009 compared to the total households that owned farmland. 
suitable for construction, but popular for fuelwood. During the year surveyed, one household cut one Neem tree for construction purposes, and another household cut one Pongamia tree for fuelwood. Of several uses for Neem and Pongamia, the seeds were the only part that was sold, and they were used for producing oil (Table 1). People collected dropped seeds from the ground by hand without tools.

Of a total of 287 trees held by the sample households, 94.1\% were arranged along the farm boundaries, namely on paths about one meter in width (Fig. 4). There were seven households that arranged Neem trees on cultivated land and one household that did so with Pongamia trees (Table 2). Ease of collecting fallen seeds might be one of the reasons to arrange the trees on paths. In fact, all four households that kept scattered trees on their farmland advised that they were primarily kept for fodder, construction timber, and fuelwood, not for seed collection.

Masuda et al. (2002) pointed out that the number of trees randomly arranged on farmland probably decrease in accordance with the intensification of technologies applied for farming: from hoeing to ploughing, and then mechanization. However, our survey revealed that the average number of trees in the $\mathrm{OC}$ and $\mathrm{O}$ groups was larger in the 11 households that ploughed than in the 19 households that hoed: 3.45 trees $\cdot \mathrm{ha}^{-1}$ in the ploughing group and 2.46 trees.ha ${ }^{-1}$ in the hoeing group. The trees that were mostly arranged along farm boundaries did not disturb ploughing, and it is likely that the utility of the leaves for fodder affected the denser number of trees per area in the ploughing group.

Regarding reproduction, one household answered that they had planted 10 Neem seedlings around 1995 for construction use, and that they felled all of them in 2008. This household was included in the $\mathrm{N}$ group during the

Table 1. Number of households by the major purpose for maintaining TBOs (August 2009).

\begin{tabular}{|c|c|c|c|c|c|}
\hline \multirow{2}{*}{ Parts } & \multirow{2}{*}{ Purpose } & \multicolumn{2}{|c|}{ Neem } & \multicolumn{2}{|c|}{ Pongamia } \\
\hline & & Household & (\%) & Household & (\%) \\
\hline \multirow{3}{*}{ Seeds } & Sale for oil & 7 & $(25.0)$ & 9 & $(56.3)$ \\
\hline & Fertilizer & 1 & ( 3.6$)$ & 1 & $(3.6)$ \\
\hline & Medicine & 1 & ( 3.6$)$ & - & \\
\hline \multirow{2}{*}{ Wood } & Timber & 14 & $(50.0)$ & - & \\
\hline & Firewood & - & - & 5 & $(31.3)$ \\
\hline Leaves & Fodder & 5 & $(17.9)$ & - & \\
\hline Whole & Shade & - & - & 1 & $(3.6)$ \\
\hline \multicolumn{2}{|c|}{ Total } & 28 & $(100.0)$ & 16 & $(100.0)$ \\
\hline
\end{tabular}

survey period.

\section{Socio-economic characteristics of the households categorized by the relation with TBOs}

The 30 households who owned TBOs were divided into $\mathrm{O}$ group (15) and OC group (15). The 20 households without TBOs were divided into $\mathrm{C}$ group (8) and $\mathrm{N}$ group (12).

TBOs were collected by household members, except in one case which hired laborers. This exceptional household owned 95 trees on 8.0 ha; both the number of trees and area of land largely exceeded that of the other households. In regard to the average number of trees excluding outliers, there was no significant difference between the OC and O groups: 8.7 and 7.0 trees $\cdot \mathrm{ha}^{-1}$ and 7.7 and 5.6 trees-per household, respectively (Table 3). The correlation coefficient of trees to land area was 0.637 , which increases when the outliers are included.

Significant difference among the three groups related to TBOs was found in the variable related to land area according to the Kruskal-Wallis test $(a=0.01$, $P=0.010)$. Land area of $\mathrm{C}$ group was the smallest according to the Steel-Dwass test, (OC-C: $\mathrm{a}=0.05, P=0.012$;

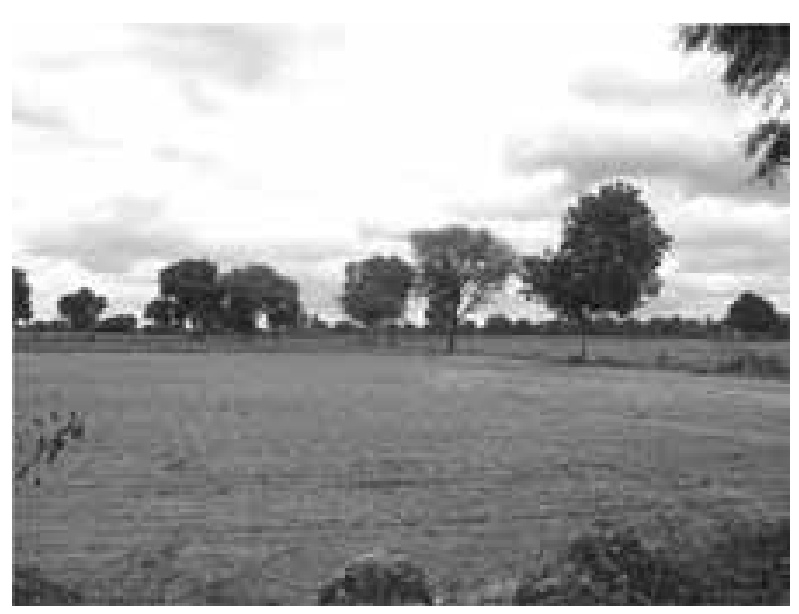

Fig. 4. TBOs arranged along farm boundaries (August 2009).

Table 2. Number of households and trees by spatial arrangement (August 2009).

\begin{tabular}{cccccc}
\hline Species & & Boundaries & Farmland & Both & Total \\
\hline \multirow{2}{*}{ Neem } & Household & 21 & 3 & 4 & 28 \\
& Tree & 176 & 15 & - & 191 \\
\hline \multirow{2}{*}{ Pongamia } & Household & 15 & 1 & 0 & 16 \\
& Tree & 94 & 2 & - & 96 \\
\hline
\end{tabular}


O-C: $\mathrm{a}=0.05, P=0.028)$. The ratio of educated household heads was also smallest in $\mathrm{C}$ group.

The main income source of the two groups that owned TBOs was agriculture. The average gross income of $\mathrm{C}$ group was the lowest (Table 4). The average total income was highest in $\mathrm{N}$ group as four households that had income from permanent employment were included. On the other hand, a larger part of landless households was also included in $\mathrm{N}$ group, which resulted in the highest economic disparity among the households in this group. In regard to income level, however, no statistically significant difference was found among the groups.

Average cash income derived from TBOs was only 2,107 Rs. (3.9\% of the total gross income) in the OC group. It was more negligible, 188 Rs. $(0.4 \%)$, in the C group. According to the Mann-Whitney test, income from TBOs was significantly lower $(\mathrm{a}=0.05, P=0.045)$ in the $\mathrm{C}$ group. As we have revealed that the major purpose behind maintaining trees was timber for Neem and fuelwood for Pongamia, the role of trees on farmlands should be sought in their multi-purpose functions rather than in the cash income from TBOs alone.

\section{Characteristics of TBO collectors}

The people of $\mathrm{C}$ group harvested TBOs without permission from the owners, but the owners did not consider such behavior as a problem. Of a total working population of 169 (82 men and 87 women), 36 people (21.3\%) engaged in TBO collection for sale in the year surveyed, and among them 26 people $(72.2 \%)$ were women. The average age of the female collectors was 40.7 , higher than the average age of the female noncollectors, which was 33.6. The relatively high age of the TBO collectors reflected their lower educational background. The education scheme in Karnataka State consists of: compulsory education (forms 1 to 5), higher primary education (forms 6 and 7), middle education (forms 8 to 10), and higher middle education (forms 11 and 12). Among all 26 female TBO collectors, 17 (65.4\%) had no education.

A total of 38 TBO collectors can be categorized as follows: the $\mathrm{C}$ group consisted of women only (9) and the OC group consisted of both women (19) and men (10). Of eight households categorized to $\mathrm{C}$ group, one household let children under the age of 15 collect TBOs, but the products were sold by the head of the household. Among these three groups, significant difference was found in educational background (ANOVA: $P<0.05$ ). None of the collectors in $\mathrm{C}$ group had an education, and this group also had the highest average age.

Table 3. Characteristics of households categorized by TBO holdings (August 2009) and seed collection (2008/2009).

* The average tree number and land area excludes an outlier belonging to the OC group.

\begin{tabular}{|c|c|c|c|c|c|c|c|c|c|}
\hline \multirow[b]{2}{*}{ HH category } & \multicolumn{3}{|c|}{ Relation with TBOs } & \multicolumn{2}{|c|}{ Av. Tree no. } & \multirow{2}{*}{$\begin{array}{l}\text { Av. land area } \\
\text { (ha) }\end{array}$} & \multicolumn{2}{|c|}{ HH head } & \multirow{2}{*}{$\begin{array}{c}\text { Av. HH } \\
\text { members }\end{array}$} \\
\hline & $\begin{array}{c}\text { Tree } \\
\text { holding }\end{array}$ & $\begin{array}{c}\text { TBOs } \\
\text { collection }\end{array}$ & HH no. & Per HH & Per ha & & Av. age & $\begin{array}{c}\text { Educated } \\
(\%)\end{array}$ & \\
\hline $\mathrm{OC}$ & + & + & 15 & $7.7^{*}$ & $8.7^{*}$ & $0.88^{*}$ & 48.5 & 60.0 & 5.2 \\
\hline $\mathrm{O}$ & + & - & 15 & 5.6 & 7.0 & 0.80 & 45.1 & 60.0 & 5.3 \\
\hline $\mathrm{C}$ & - & + & 8 & - & - & 0.30 & 46.8 & 12.5 & 4.4 \\
\hline $\mathrm{N}$ & - & - & 12 & - & - & 0.34 & 42.5 & 50.0 & 5.1 \\
\hline Total & & & 50 & & & 0.62 & 45.7 & 50.0 & 5.0 \\
\hline
\end{tabular}

Table 4. Average annual gross income by household category related to TBOs and by source of income (2008/2009). Agricultural sales include those from TBOs. Others consist of remittance and sale of firewood.

\begin{tabular}{|c|c|c|c|c|c|c|c|c|c|c|c|c|c|c|}
\hline \multirow{2}{*}{$\begin{array}{c}\mathrm{HH} \\
\text { category }\end{array}$} & \multirow{2}{*}{$\begin{array}{l}\mathrm{HH} \\
\text { no. }\end{array}$} & TBO sale & \multicolumn{2}{|c|}{$\begin{array}{l}\text { Agricultural } \\
\text { sale }\end{array}$} & \multicolumn{2}{|c|}{$\begin{array}{c}\text { Animal } \\
\text { husbandry }\end{array}$} & \multicolumn{2}{|c|}{$\begin{array}{l}\text { Daily wage } \\
\text { labor }\end{array}$} & \multicolumn{2}{|c|}{$\begin{array}{c}\text { Regular } \\
\text { employment }\end{array}$} & \multicolumn{2}{|c|}{ Others } & \multicolumn{2}{|c|}{ Total } \\
\hline & & $(\%)$ & Rs & (\%) & Rs & (\%) & Rs & $(\%)$ & Rs & $(\%)$ & Rs & (\%) & Rs & (\%) \\
\hline $\mathrm{OC}$ & 15 & 2,107 ( 3.9) & \multicolumn{2}{|c|}{$21,706(39.9)$} & \multicolumn{2}{|c|}{$4,019(7.4)$} & \multicolumn{2}{|c|}{$15,690(28.8)$} & \multicolumn{2}{|c|}{$8,893(16.3)$} & \multicolumn{2}{|c|}{$2,000(3.7)$} & 54,415 & $\overline{(100.0)}$ \\
\hline $\mathrm{O}$ & 15 & - & \multicolumn{2}{|c|}{$19,291(40.9)$} & \multicolumn{2}{|c|}{$5,499(11.7)$} & \multicolumn{2}{|c|}{$11,463(24.3)$} & \multicolumn{2}{|c|}{$1,867(4.0)$} & \multicolumn{2}{|c|}{$9,000(19.1)$} & 47,119 & $(100.0)$ \\
\hline $\mathrm{C}$ & 8 & $188(0.4)$ & \multicolumn{2}{|c|}{$5,081(11.8)$} & \multicolumn{2}{|c|}{$10,358(24.1)$} & \multicolumn{2}{|c|}{$16,875(39.3)$} & \multicolumn{2}{|c|}{$7,875(18.3)$} & \multicolumn{2}{|c|}{$2,550(5.9)$} & 42,926 & $(100.0)$ \\
\hline $\mathrm{N}$ & 12 & - & \multicolumn{2}{|c|}{$14,351(19.0)$} & \multicolumn{2}{|c|}{$7,000(9.3)$} & \multicolumn{2}{|c|}{$27,525(36.5)$} & \multicolumn{2}{|c|}{$11,100(14.7)$} & \multicolumn{2}{|c|}{$15,500(20.5)$} & 75,476 & $(100.0)$ \\
\hline Total & 50 & $662(1.2)$ & \multicolumn{2}{|c|}{$15,019(27.3)$} & \multicolumn{2}{|c|}{$6,719(12.2)$} & \multicolumn{2}{|c|}{$17,888(32.5)$} & \multicolumn{2}{|c|}{$7,434(13.5)$} & 7,26 & (13.2) & 54,984 & $(100.0)$ \\
\hline
\end{tabular}


Table 5. Average age and educational background of TBO collectors (August 2009).

\begin{tabular}{|c|c|c|c|c|c|c|}
\hline \multirow{2}{*}{\multicolumn{2}{|c|}{ Group }} & \multirow{2}{*}{$\mathrm{n}$} & \multicolumn{2}{|c|}{ Age } & \multicolumn{2}{|c|}{ Education } \\
\hline & & & Mean & $\mathrm{SD}$ & Mean & $\mathrm{SD}$ \\
\hline $\mathrm{OC}$ & (male) & 10 & 37.1 & 3.3 & 7.8 & 1.4 \\
\hline $\mathrm{OC}$ & (female) & 19 & 38.5 & 2.4 & 4.1 & 1.1 \\
\hline $\mathrm{C}$ & (female) & 9 & 44.3 & 3.0 & 0.0 & 0.0 \\
\hline
\end{tabular}

\section{Distribution of TBOs and Utilization as Biofuel}

Whether middlemen visit the village and whether a part of the village population starts specializing in mercantile transactions or working as agents for such transactions can be indicators that a production area has formed. Of 23 households collecting TBOs for sale during the year surveyed, however, only three households sold the seeds to buyers who came to the village, and the majority of households sold TBOs at Gauribidanur town. The collectors of TBOs were mainly women, but the sellers were mainly men (19 households).

All of the five shops we interviewed purchased not only Neem and Pongamia seeds but also coconuts and groundnuts. The shops were selling the TBOs directly, or through APMCs, to the oil mills. In addition, one mill bought TBOs directly from the collectors. The oil produced at the factory was distributed to various users. Neem oil was sold to and reprocessed at soap factories and pharmaceutical factories. Pongamia oil was sold to leather factories and lubricant factories. Part of the Pongamia oil was also sold to consumers, including the collectors, through the buyers, as fuel for their lamps. Oil shell was sold as fertilizer to large-scale farmers (Fig. 5). The average buying price of the five shops had risen since 2006, from 15.3 Rs. (Neem) and 12.6 Rs. (Pongamia) $\mathrm{kg}^{-1}$ in 2006 to 18.8 and $15.3 \mathrm{Rs}^{\mathrm{kg}} \mathrm{kg}^{-1}$ in 2009.

Neither the TBO collectors nor buyers knew that Neem and Pongamia oil could be processed into biodiesel. Only the managers of the two oil mills knew that fact. Some of the buses running in Karnataka used diesel oil, including $10 \%$ of fuel derived from Pongamia. According to interview responses, the oil factories in Gauribidanur had been selling Pongamia oil to the Karnataka State Road Transport Corporation (KSRTC) in 2007, but in 2009 KSRTC was buying biodiesel made of Pongamia oil and coconut oil from Andhra Pradesh State.

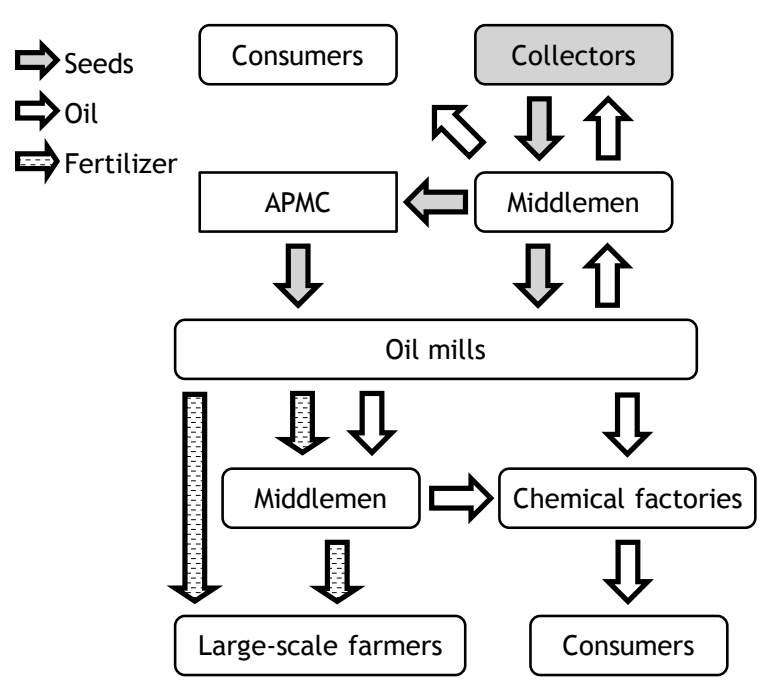

Fig. 5. Distribution of TBOs in Gauribidanur taluk.

\section{DISCUSSUION}

We found that Neem and Pongamia scattered in semi-arid India were multi-purpose trees, which had various utilities. Using those trees for oil extraction was only one of these uses. Over-matured trees can be utilized as timber or fuelwood, which is a renewable energy source. In addition, Neem and Pongamia were collected during seasons without agricultural crop harvests, and provided additional income. Since seed collection is harmless to tree growth and the seeds are not edible, we can predict that utilization for oil, including biofuel, will not cause direct forest loss or food conflict, but that it could contribute to carbon sequestration.

The reasons trees were arranged mainly along the boundaries of agricultural fields in this study's D Village, despite the multiple functions of the trees, were to avoid competition between the trees and crops, to make it easier to collect the seeds, and to avoid interfering with ploughs. The households kept livestock for several reasons, including ploughing, and dense clusters of trees in fields could become obstructions.

This scarce allocation of TBOs resulted in contradictory roles in the rural economy. TBOs as a means of minor subsistence allowed treeless people to engage in seed collection from trees held by other people without charge. Thus, TBOs in D Village can be regarded as a common pool resource despite the trees themselves being private property. Among the three groups that were involved in TBOs, namely the OC, O, and $\mathrm{C}$ groups, the average land area of $\mathrm{C}$ group was significantly small. Among the collectors, there were more women than men, 
and elder women with less education tended to engage in seed collection. The tendency was most apparent in C group collectors: all were women without educational background. These results support previous studies emphasizing the significance of NTFPs for the rural poor and the socially weak. Nevertheless, contribution of TBOs to the enhancement of the economic conditions of the socially weak was negligible, accounting for only $0.4 \%$ of the total gross income in $\mathrm{C}$ group, which was significantly smaller than that of OC group. The economic importance of TBOs is found in their multiple functions provided by various parts of the trees, and only a limited part, namely seeds, was available to the public.

The sanction for treeless people to collect TBOs from others' land means that the seeds in situ are valueless unless labor is devoted for collection. Once the seeds on the trees gain value with the market growth, as in the transactions of unharvested crops, the current common-resource nature of TBOs could become exclusive private property. The land might be used more efficiently and the production of TBOs might be enhanced. Eventually, the households of $\mathrm{C}$ group may be excluded from TBO activities that they now carry out independently, most likely to be reorganized as harvest laborers, and benefiting less from increases in the price.

Another issue to be discussed is whether the reproduction of TBOs is guaranteed or not. In the case of D Village, only one household responded that they had planted TBOs. In particular, trees that are left on trodden paths are difficult to regenerate naturally. Therefore, if the demand for biofuel rises in the future, there should be a program to encourage households to replant TBOs regardless of their economic constraints, and it might be practical to link those programs with the state government's social forestry programs. In Karnataka State, the Department of Environment and Forests as well as the Department of Village Development started plantations of Pongamia in 2008. This program has been implemented with the aim of increasing the production of biofuel, reforesting the wasteland, and alleviating poverty. By 2009, Pongamia had been planted in 2,300 ha of wasteland. If the expansion of TBOs can keep pace with market growth, or exceed demand, the seeds may remain a common pool resource. Although this may keep profitability low, it would allow socially disadvantaged households to share in the economic benefits of TBOs.

ACKNOWLEDGEMENTS This study was conducted as a part of JSPS Grant-in-Aid for Scientific Research (No. 21405005). During our study in India, we received much support from the Ministry of Environment and Forests, India, and Karnataka State Forest Department. The staff of Gauribidanur taluk generously provided documents and information. The people of D Village patiently responded to the interview questions. We would like to express our appreciation to all who cooperated with our study, and also to the reviewers for their constructive suggestions.

\section{REFERENCES}

Agoramoorthy G, Hsu MJ, Chaudhary S, Shieh P. 2009. Can biofuel crops alleviate tribal poverty in India's drylands? Applied Energy 86: S118-S124.

Altenburg T, Dietz H, Hahl M, Nikolidakis N, Rosendahl Ch, Seelige K. 2009. Biodiesel in India: value chain organization and policy options for rural development. German Development Institute, Bonn.

Belcher BM. 2005. Forest product markets, forests and poverty reduction. International Forestry Review 7(2): 82-89.

Belcher BM, Pérez MR and Achdiawan R. 2005. Global patterns and trends in the use and management of commercial NTFPs: Implications for livelihoods and conservation. World Development 33(9): 1435-1452.

[BES] Bureau of Economics and Statistics, Karnataka State. 2009. Rain record book. BES, Gauribidanur.

[EIA] US Energy Information Administration. 2011. Top world oil net importers, 2009. http://www.eia.gov/ countries/index.cfm?topL=imp (cited 2011 September 1).

Fonzen PF and Oberholzer E. 1984. Use of multipurpose trees in hill farming systems in western Nepal. Agroforestry Systems 2: 187-197.

Gedare Grama Panchayat. 2008. General information book. Gedare Grama Panchayat, Gedare.

[IIFM] Indian Institute of Forest Management. 2001. Tree Resource outside forests (TOF) in India. IIFM, Bhopal.

Jambulingam R, Fernandes ECM. 1986. Multipurpose trees and schrubs on farmlands in Tamil Nadu State (India). Agroforestry Systems 4: 17-32.

Kumar TKA. 2011. Provisional population totals: Karnataka. Directorate of Census Operations, Bangalore.

Kusters K, Belcher B (eds.). 2004. Forest products, livelihoods and conservation: case studies of nontimber forest product systems. Vol.1. Asia. CIFOR, Bogor. 
Kusters K, Achdiawan R, Belcher B, Pérez MR. 2006. Balancing development and conservation? An assessment of livelihood and environmental outcomes of nontimber forest product trade in Asia, Africa, and Latin America. Ecology and Society 11(2): article 20 [online]. http://www.ecologyandsociety. org/vol11/iss2/art20/ (cited 2011 February 15).

Masuda M, Kudu S, Aliu J, Shoji K. 2002. Potential for agroforestry as a part of integrated watershed management. In: Hirose S and Wakatsuki T (eds.) Restoration of inland valley ecosystems in West Africa. Association of Agriculture and Forestry Statistics, Tokyo. 478-499.

[MNRE] Ministry of New and Renewable Energy, the Government of India. 2009. National Policy on Biofuels. http://www.mnre.gov.in/policy/biofuelpolicy.pdf (cited February 15, 2011).

Neumann RP and Hirsch E. 2000. Commercialization of non-timber forest products: review and analysis of research. CIFOR, Bogor.

Newman SM. 1997. Poplar agroforestry in India. Forest Ecology and Management 90: 13-17.

Pérez MR and Arnold JEM (eds.). 1996. Current issues in non-timber forest products research. CIFOR, Bogor.

Ravindranath NH, Lakshmia CS, Manuviea R, Balachandra P. 2010. Biofuel production and implications for land use, food production and environment in India. Energy Policy (2010), doi:10.1016/j.enpol.2010.07.044. http://www. elsevier.com/locate/enpol (cited 2011 February 15).

[RDPR] Rural Development and Panchayat Raj Department, Karnataka State. 2009. Chikkaballapur district at a glance 2007-2008. RDPR, Bangalore.

Subramanian KA, Singal SK, Saxena M, Singhal S. 2005. Utilization of liquid biofuels in automotive diesel engines: an Indian perspective. Biomass and Bioenergy 29: 65 - 72 .

Sunderlin WD, Angelsen A, Belcher B, Burgers P, Nasi R, Santoso L, Wunder S. 2005. Livelihoods, forests, and conservation in developing countries: an overview. World Development 33(9): 1383-1402.

[UNFCCC] United Nations Framework Convension on Climate Change. 2007. Fuel switch from petro-diesel to biofuel for the transport sector in Bangalore Metropolitan Transport Corporation (BMTC), Karnataka, India. http://cdm.unfccc.int/Projects/ Validation/DB/U5H6LUXR77B4DVODY5BHUUCB 6E0IB7/view.html (cited 2011 February 15).

Wollenberg E and Ingles A (eds.). 1998. Incomes from the forest: methods for the development and conservation of forest products for local communities. CIFOR, Bogor.

Received 22 $2^{\text {nd }}$ Mar. 2011

Accepted 24 ${ }^{\text {th }}$ Oct. 2011 